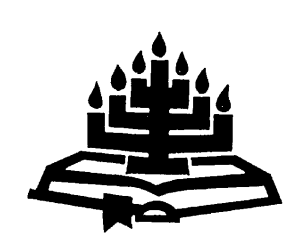

\title{
Intelligensie op drie vlakke as 'n kernvereiste vir die bedienaar
}

\author{
C.J.H. Venter \\ Eenheid vir Reformatoriese Teologie \\ Potchefstroomkampus \\ Noordwes-Universiteit \\ POTCHEFSTROOM \\ E-pos: casmar@lantic.net
}

\section{Abstract \\ Intelligence on three levels as core requirement for the pastor}

In this article the requirement that a pastor should act and behave in an intellectually, emotionally and socially intelligent way is focused on. At the outset of the article intellectual intelligence is discussed metatheoretically. The functioning of the brain, especially of the neocortex, the sub-cortex and the amygdala is outlined as far as intellectual intelligence is concerned. Basistheoretically relevant requirements for being intellectually intelligent are then investigated, in particular relevant requirements for the sound equipment of the pastor as stated in the pastoral epistles. In this respect the following aspects are scrutinised: the requirement that the pastor should have the competence to instruct the congregation from God's Word, and the requirement that the pastor should have the ability to equip his congregation in an intellectually sound way. In the ensuing part of the article metatheoretical viewpoints on emotional intelligence are outlined. Aspects like the following are indicated and mentioned as these should form part of the pastor's equipment: the value of a sound self-awareness, a clear perspective on own competencies, a founded self-confidence, self-control, the ability to minister with certain aims in mind, to handle own emotional wounds, and in the last instance, the requirement of insight and how to cope with own emotions. The requirement that the pastor should exercise self-control and the conviction of being called by and cared for by his Sender, God, are included as basistheoretical material. As far as social intelligence is concerned, the following elements are taken into consideration on metatheoretical level: the ability to have an understanding for the situation of someone else and the competence to tune into the 
feelings of another person. Aspects of the requirement to create relationships, and issues of empathy are investigated and described basis-theoretically. In conclusion practice-theoretical guidelines are formulated for a possible implementation of intellectual, emotional and social intelligence in the ministry of a servant of God.

\section{Opsomming}

\section{Intelligensie op drie vlakke as 'n kernvereiste vir die bedienaar}

In hierdie artikel word op die vereiste gefokus dat die bedienaar op 'n verstandelik-, emosioneel- en sosiaal-intelligente wyse moet kan optree en handel. Intellektuele intelligensie word aan die begin van die artikel metateoreties bespreek. Die funksionering van die brein word omlyn in sover dit raakvlakke met verstandelike intelligensie het, in besonder die breinfunksies van die neokorteks, die subkorteks en die amigdala. Onder basisteoretiese aspekte word die volgende vereistes uit die pastorale briewe betrek: die vereistes dat die bedienaar bevoegd moet wees om die gemeente uit God se Woord te onderrig en die vereiste dat hy die vermoë moet hê om op 'n verstandige wyse te handel. Vervolgens word metateoretiese aspekte van emosionele intelligensie aangedui, waaronder ' $n$ goeie selfbewussyn, 'n helder beskouing van die eie vermoëns, gefundeerde selfvertroue, selfbeheer, om met doelwitte te kan werk, die hantering van die eie emosionele letsels, en insig in en hantering van die eie emosies. Hierdie vereistes word in die bespreking betrek juis omdat dit deel van die pastor se bedieningswyse raak. As basisteoretiese perspektiewe op emosionele intelligensie is veral die aspekte van empatie en die geborgenheid van die bedienaar betrek. Ten opsigte van sosiale intelligensie is metateoreties gestel dat dit 'n kernvereiste is om 'n ander se situasie te kan verstaan, aan te voel en op die ander persoon se gevoelens te kan inspeel. Die proses van verhoudingsvorming en die betoon van empatie is op basisteoretiese wyse nagegaan en nader omskryf. Ten slotte is praktykteoretiese riglyne gebied vir die moontlike implementering van verstandelike, emosionele en sosiale intelligensie in die werk en toerusting van 'n dienskneg van God.

\section{Oriëntering}

In wetenskaplike ondersoeke in die jongste tyd in die veld van die Praktiese Teologie is dit opvallend dat daar nie net 'n gerigtheid is op die optrede van die bedienaar in byvoorbeeld herderlike sorg, prediking en jeugsorg nie, maar ook op die persoon van die bedienaar wat handel en optree. Ironies genoeg, aanvaar gemeentelede 
geredelik dat die bedienaar 'n gestuurde van God is; hulle erken dat die Heilige Gees die bedienaar in sy werk rig en lei, maar in die praktyk en praktiese bedieningswyse van die bedienaar verwag hulle ook 'n (menslik) afgeronde en deurdagte wyse van optrede wanneer die bedienaar sy werk doen. Die wyse waarop die bedienaar op 'n verstandelik-, emosioneel- en sosiaal-intelligente vlak optree, speel dus ook ' $n$ rol in die vereistes wat aan die bedienaar gestel word. Daar gaan ook stemme op dat hierdie vereistes in die opleiding van predikante verdere aandag moet ontvang.

In navorsing word daarom meermale gefokus op gegewens wat lig werp op die handelswyse en persoon van die bedienaar. In hierdie verband kan gedink word aan die tersaaklike gegewens oor die handelswyse van die bedienaar soos dit in die pastorale briewe na vore kom (vgl. Quinn \& Wacker, 2000; Stott, 1997), die spiritualiteit van die prediker en herder (Kim \& Venter, 1998:161-179; Venter, 1999; Dreyer, 2003; Montoya, 2000), die moontlike aggressiewe optrede van 'n bedienaar (Venter, 2004), die persoonlikheid van die bedienaar (Greenfield, 2001; Kruger, 2000), streshantering deur die bedienaar (Nel, 2001; Venter, 2005b; Grobbelaar, 2007), en "medelyemoegheid" by die bedienaar (Fourie, 2008). Aspekte van die gesindheid waarin gedien word, ontvang ook wetenskaplike aandag (Kruger \& Venter, 2000) en daarmee saam die bedienaar se eie belewing van die bediening. Ook die moontlike verwonding van die bedienaar in die bedieningsituasie word nader betrek in navorsing (Notle \& Dreyer, 2009).

Sommige van bogenoemde aspekte word ook betrek in vrae oor die roeping en opleiding van bedienaars. Nel (2005:454-455) formuleer die volgende vaardighede wat van predikante vereis word in die konteks van die hedendaagse bediening: kennis, insig, die regte gesindheid en ingesteldheid. Hy beklemtoon ook dat bedienaars sinvol en met begrip en insig met gemeentelede moet kan kommunikeer. In hierdie bedieningswyse moet die gesindheid van die bedienaar een van diens wees - die pastor moet beweeg van blote diens lewer na diensbaar wees (Nel, 2005:458-459).

Dit is juis by die vereistes van kennis en insig, vaardigheid en oriëntasie of ingesteldheid van die pastor waarby hierdie artikel aansluit met 'n poging om dit byeen te bring, te integreer en verder uit te bou. Nie net in die Skrif word perspektiewe oor bogenoemde aspekte van kennis, vaardigheid, ingesteldheid en gesindheid gebied nie, maar ook in wetenskappe wat aan vakke in die Praktiese Teologie grens, soos byvoorbeeld Pastorale Teologie. 
In hierdie artikel kan nie dieper ingegaan word op die verhouding tussen Pastoraal en Psigologie nie. Dit is 'n onderwerp waaroor reeds breed besin is (vgl. Kruger \& Venter, 2001:557-574; Hugo, 2008:107-126; Dreyer, 2008:3-22). In hierdie artikel word slegs, sonder breër beredenering, gestel dat daar 'n hermeneutiese wisselwerking behoort te bestaan tussen basisteorie en metateorie met die oog op die praksis van die pastorale bediening. Verder moet voortdurend in gedagte gehou word dat die wetenskap 'n eenheid is. Wie dus Praktiese Teologie beoefen sonder om gegewens vanuit metateoretiese data te betrek, loop die gevaar om die wetenskap fragmentaries te beoefen. Voorts is nie net die wetenskap nie, maar ook die bedienaar aan wie die vereistes van intelligensie op drie vlakke gestel word, 'n eenheid wat nie net religieus nie, maar ook fisies en psigies funksioneer. Juis om hierdie rede word in hierdie navorsing by Teologie ook die Psigologie en Neurologie nader betrek.

In hierdie verband kan verwys word na die opkoms van die sogenaamde ondersoekvelde van Emosionele (EI) en Sosiale Intelligensie (SI). Albei hierdie navorsingsgebiede in die Sielkunde is verder in navorsing ontwikkel (vgl. Gardner, 1993). Resente eksponente van hierdie ondersoekterreine is Goleman en Albrecht. By emosionele $(\mathrm{El})$ en sosiale intelligensie (SI) moet egter ook die vereiste van verstandelike intelligensie (die sogenaamde IK) gevoeg word. Van der Walt $(2007: 31,32)$ beredeneer dat ons verstand 'n wesenlike funksie in die godsdiens vervul. Ons moet God immers nie net met ons hele hart liefhê nie, maar ook met ons hele verstand.

In hierdie artikel vir 'n gewaardeerde leermeester, is die sentrale probleemstelling 'n nadere fokus op die drie vlakke van intelligensie wat as kernvereistes sou kan geld vir die bedienaar se werkwyse in die gemeente. Aansienlike besinning hieroor het reeds op die vlak van die Psigologie plaasgevind. Hierdie artikel is 'n poging om uit eie en ander outeurs se navorsing materiaal byeen te bring oor die drie soorte intelligensie. Met hierdie verkenning word gepoog om aan te dui watter vereistes gestel word vir die bedienaar om verstandelik, emosioneel en sosiaal intelligent op te tree. Binne die sentrale navorsingsvraag sal aandag gewy word aan die volgende sake: Watter verbandhoudende metateoretiese perspektiewe kan nadere lig werp op die kennis, vaardighede, oriëntering of ingesteldheid van die pastor? Watter bydraes kan basisteoretiese perspektiewe lewer op verstandelike, emosionele en sosiale intelligensie? Watter praktykteoretiese perspektiewe kom uit hierdie besinning na vore? 


\section{Metateoretiese perspektiewe}

Vir die doeleindes van die artikel word aan die begin van elke onderafdeling metateoretiese perspektiewe gebied, onderskeidelik op verstandelike intelligensie, daarna op emosionele intelligensie en laastens op sosiale intelligensie. Daarna word in elke onderafdeling ook basisteoretiese perspektiewe in dieselfde volgorde gebied.

\subsection{Metateoretiese perspektiewe op verstandelike intelligensie}

Wat in hierdie opsig veral van belang is, is enkele toepaslike navorsingsresultate vanuit die Neurologie op die samestelling en funksionering van die brein. Daar is verskeie sentra in die brein wat die verskillende vlakke van intelligensie omvat, bepaal en beïnvloed.

Vir verstandelike intelligensie is dit van belang om in gedagte te hou dat die setel daarvan in die brein se sogenaamde neokorteks is.

The neocortex is the seat of thought, it contains the centers that put together and comprehend what the senses perceive. It adds to a feeling what we think about it - and allows us to have feelings about ideas, art symbols, imaginings." (Goleman, 1998: 317.)

Die neokorteks, geleë aan die bokant van die brein, se werking bepaal die intellek, strategieë vir oorlewing, langtermynbeplanning, verhoudingsvorming en geheue, maar bepaal ook die ontwikkeling van kuns, kultuur en beskawing (vgl. LeDoux, 1996; Goleman, 2006:10-11).

Die sentrum in die brein wat emosionele hoedanighede huisves, is laer af in die brein gesetel en word die subkorteks genoem (Bechara et al., 2000:196-202). Verder in hierdie artikel sal beredeneer word dat emosionele intelligensie daarin bestaan dat die subkorteks (die sentrum van die emosies) in harmonie met die setel van die intellek (die neokorteks) werk.

Vanuit die Neurologie kan die werking van die sogenaamde amigdala nagegaan en omlyn word. Die amigdala is amandelvormige organe in die anteriordele van die temporale lobbe van die brein, sowel aan die linker- as aan die regterkant. Die amigdala vorm deel van die sogenaamde limbiese brein en het 'n uitgebreide neurologiese netwerk (vgl. Taylor \& Bagby, 2000:51-52), wat ten nouste verbind word met emosies in die subkorteks. Uit die eie omgewing (deur visie, gehoor, pyn-, tas- en reuksensasie) kom die amigdala in 
werking en aktiveer twee roetes na 'n bepaalde reaktiewe optrede. Die eerste - deur Goleman genoem die low road - is die veg- of vlugreaksie wat blitsvinnig in werking gestel word. Die tweede weg deur Goleman genoem die high road - volg 'n langer roete. Die inligting uit die omgewing word eers verwerk in die talamus wat op sy beurt die inligting na die korteks herlei. Ná hierdie ompad stel die korteks die persoon in staat om die gevaar in konteks te sien en 'n meer besonne besluit te neem en nie in emosionele highjacking (vgl. Burnard, 1992:70; Goleman, 1997:19-20) of 'n woedeuitbarsting te verval nie. Die amigdala is ook 'n bergplek van herinnerings uit die verlede. Wanneer iemand byvoorbeeld meen hy is deur ' $n$ ander persoon veronreg, word hierdie negatiewe ervarings uit die verlede ook opgeroep in 'n situasie van aggressie en dra die gebeure uit die verlede sodoende verder by tot en versterk die uiting van woede in die hede (vgl. Vermeulen, 1999:50-53; Van Jaarsveld, 2003:10; Venter, 2005b:19-20).

\subsection{Basisteoretiese perspektiewe op verstandelike intelligensie}

Vervolgens word in hierdie gedeelte dieper ingegaan op Nuwe-Testamentiese gedeeltes waarin vereistes gestel word vir die verstandelike intelligensie van die bedienaar. In die Nuwe Testament word byvoorbeeld gestel dat die bedienaar bekwaam moet wees om te leer, dat hy die vermoë moet hê om verstandig op te tree en die gemeente te kan toerus.

\subsubsection{Bekwaam om te leer}

Die uitdrukking dat die bedienaar "bekwaam moet wees om ander te leer" (didaskein) kom minstens drie maal in die pastorale briewe voor, naamlik 1 Timoteus 3:2 en 2 Timoteus 2:2 en 4. Die begrip didaskein word hier gebruik in die betekenisveld van "to provide instruction in a formal or informal setting - to teach, or: teaching" (Louw \& Nida, 1989:413). In die genoemde verwysings uit Timoteus word dus nie alleenlik klaskameraktiwiteit bedoel nie, maar ook leeraktiwiteit deur identifikasie - ook op informele vlak. Dit moet in gedagte gehou word dat in die pastorale briewe, die mees sentrale openbaring oor die bedienaar se vereistes en optrede, nie minder nie as nege verkondigingsbegrippe voorkom (Venter, 1976:108). Didaskein is een van die nege begrippe en dui onder andere op ontvouende verkondiging of lering. Die vereiste dat 'n bedienaar bekwaam moet wees om ander te leer, word ook telkens in ander vorms herhaal (leermeester in $1 \mathrm{Tim}$. 2:7; leer(stellig) in $1 \mathrm{Tim} .4: 13$, 4:16 en 2 Tim. 2:2). In die pastorale briewe word die konsep van 
leer sentraal geplaas in die vereistes wat vir die bedienaar gestel word. Dit is ook insiggewend dat die leeraksie in die pastorale briewe vyf keer gerig word op lering in die gemeente en twee keer op lering van die heidene.

Hierdie leeraktiwiteit het 'n besliste verstands- of denkdimensie en kan beskou word as 'n charisma wat die Heilige Gees aan die bedienaar uitdeel (vgl. Ef. 4:7, 11 en 12; Rom. 12:6-8). Om ontvouend te kan leer, vereis 'n bepaalde insig en onderskeiding in die stof wat geleer word, in die persone wat onderrig ontvang en gee, en in die wyse waarop geleer word.

Met die aksie van leer hang ook saam dat die gesonde leer wat "in ooreenstemming met die evangelie is" (1 Tim. 1:11) geleer moet word en dat "gesonde en onaanvegbare" prediking (Tit.1:8) moet plaasvind. Hiervoor word die vermoëns van onderskeiding, analise, interpretasie en sintese vereis. Juis daarom moet die bedienaar vashou aan "die betroubare woord waarin hy self onderrig is" (Tit. 1:9).

In Efesiërs 4:11 en 12 word gestel dat God sekere bedieningsgawes gegee het (onder andere herders en leraars) met die doel dat die gemeente toegerus moet word. Die konsep wat in Efesiërs vir toerusting gebruik word - katartidzo - het 'n wye gebruiksveld buite en in die Nuwe Testament. As mediese term hou dit byvoorbeeld in om die betrokke liggaamsdeel wat uit lit is, tot die regte posisie te manipuleer. As atletiekterm beteken dit om af te rig, as pastorale term om reg te help (Gal. 6:1) en ook om aan te vul wat nog by die gemeente se geloof ontbreek (1 Tess. 3:10). Hierdie toerusting van die gemeente gaan gepaard met eie leer- en denkaktiwiteite, met die bemeestering en eie maak van kennis deur die onderrig wat die bedienaar self ontvang het, en ook deur die vermoë om hierdie kennis oor te dra. Hiervoor is insig en gesonde denke noodsaaklik.

\subsubsection{Verstandig wees}

Die vereiste dat die bedienaar verstandig moet optree, word in Titus 1:8 gestel. Arndt en Gingrich (1979:802) toon aan dat die begrip sophron wat hier gebruik word, nuanses het van optrede wat gerig word deur insig, asook gesonde en rasionele denke - in teenstelling met abnormale of ongesonde denke.

As konklusie van die besinning in hierdie onderafdeling kan gestel word dat verstandelike intelligensie 'n kernvereiste vir die bedienaar is vir die onderrig, leer en toerusting van die gemeente. Die pastor 
het egter ook verstandelike intelligensie nodig om verstandig, dit wil sê met insig en oorwoëndheid, te kan optree.

\section{Perspektiewe op emosionele intelligensie}

\subsection{Metateoretiese perspektiewe}

Dit is noodsaaklik om vooraf op hierdie punt in die artikel kortliks agtergrondinligting te verskaf oor die ontstaan en ontwikkeling van die vakrigting, Emosionele Intelligensie, vanuit die Psigologie. Salovey et al. (2002:160) sluit in hulle navorsing aan by 'n stelling wat Mowrer reeds in die sestigerjare gemaak het: "... the emotions do not at all deserve being put in opposition with intelligence ... they are, it seems, themselves a higher order of intelligence". Salovey et al. (2002:160) omskryf emosionele intelligensie fyner as die vermoë van 'n persoon om sy eie gevoelens en dié van ander te verstaan en om hierdie emosies as inligting en gids vir denke en optrede te gebruik (vgl. Venter, 2005b:12).

Goleman et al. (2002:102-104) sluit by genoemde outeurs aan en omskryf emosionele intelligensie as die vermoë om ons eie gevoelens en dié van ander te herken, om onsself te kan motiveer en om ons eie en ander se gevoelens in onderlinge verhoudings te kan hanteer.

\subsubsection{Die vaardigheid om emosioneel intelligent op te tree}

Die vaardigheid om emosionele intelligensie te implementeer, omvat vyf dimensies (vgl. Venter, 2005b:14):

- selfbewussyn: om te weet wat jy op 'n bepaalde oomblik self voel en dit in besluitneming te implementeer; om 'n nugter beskouing van die eie vermoëns en 'n gefundeerde gevoel van selfvertroue te hê;

- selfbeheer: (om die eie emosies te hanteer, om betroubaar en nougeset te wees, om beloning te kan uitstel, bepaalde doelwitte na te streef, om goed te herstel van emosionele letsels en om innoverend en aanpasbaar te wees;

- selfmotivering: om voorkeure te benut om doelwitte te berei;

- empatie: om te voel wat ander voel; en

- sosiale vaardighede: om emosies in verhoudings goed te kan hanteer, emosionele situasies reg te kan opsom, eie vaardighede te kan gebruik om te oortuig, leiding te neem, te onderhandel, 
verskille op te los, te kan saamwerk in spanverband en om goed en helder te kan kommunikeer.

\subsubsection{Die vernaamste tipe emosies wat mense ervaar}

Bedell en Lennox (1997:68) onderskei die volgende vier emosies as die vernaamste emosies wat mense ervaar:

- vrees: wanneer iemand verwag dat iets gaan gebeur wat hy/sy nie wil hê moet gebeur nie;

- woede: wanneer iemand voel dat hy/sy iets wil hê, dit nie kry nie, maar steeds wil hê;

- droefheid: die ervaring as 'n persoon iets graag wil hê, dit nie kry nie en hoop opgee om dit ooit te kry; en

- gelukkigheid: die ervaring wanneer iemand graag iets wil hê en dit wel kry.

Dit is nodig om in gedagte te hou dat emosies, byvoorbeeld vrees, meestal nie ontstaan uit wat 'n situasie in werklikheid is nie, maar uit wat 'n persoon dink die werklikheid is. Daar is 'n noue verband tussen gedagte en gevoel. 'n Gedagte is 'n boodskap van die brein wat 'n wens, begeerte of verwagting impliseer. Hierdie gedagtes dien as 'n sneller vir die aktivering van gevoelens. Die belangrike afleiding wat ons op grond van hierdie genoemde proses maak, is dat gevoelens as gevoelens hulle oorsprong in denke vind. Gevoelens as gevoelens verander dus nie, maar dit wat 'n mens dink, die oorsprong van gevoelens, kan verander en beheer word (Vermeulen, 1999:43) deur jou denke daaroor te verander.

Uit die kort oorsig oor emosionele intelligensie is dit duidelik dat emosionele intelligensie veral in die persoonlike lewe funksioneer en daarom ook op die vlak van die bedienaar in sy bediening.

Saamgevat: Aspekte van emosionele intelligensie soos selfbewussyn, selfmotivering, empatie en selfbeheersing behoort die bedienaar te bring tot selfinsig in sy eie gevoelens, motiewe en emosies. Emosionele intelligensie funksioneer dus op die vlak van die bedienaar se persoonlike lewe in die bedieningswerk. 


\subsection{Basisteoretiese perspektiewe op emosionele intelligensie}

\subsubsection{Selfbeheersing}

Dit is reeds beredeneer dat in 1 Timoteus 3:2-7 en in Titus 1:6-9 aan die bedienaar bepaalde vereistes gestel word. Hierdie vereistes kan in bepaalde onderdele verdeel word. Daar is byvoorbeeld nie net vereistes wat verband hou met verstandelike vermoëns nie, maar ook ander vereistes wat direk betrekking het op die gedrag, karakter, of optrede na buite van die bedienaar (Armstrong, 1990:127).

Onder basisteoretiese vereistes wat verband hou met verstandelike intelligensie is aandag gegee aan die vereistes dat ' $n$ bedienaar bekwaam moet wees om te onderrig, verstandig te kan optree, die gemeente te kan toerus en dus dat hy insig en 'n gesonde verstandsoordeel moet hê.

Met al hierdie verstandelike vereistes hang ook die emosionele vereiste van selfbeheersing saam. In hierdie verband word ook verwys na die uiteensetting oor die funksie en werking van emosies wat by bepaalde denke begin, asook na die werking van die amigdala in die brein.

Die vraag moet egter gevra word of die Skrif self toepaslike perspektiewe op enkele aspekte van emosionele intelligensie bied.

\subsubsection{Bedienaar en selfbeheersing}

Die vereiste in die pastorale briewe wat betrekking het op selfbeheersing, is dat die bedienaar nie 'n rusiemaker (plektes) moet wees nie (1 Tim. 3:3). Plektes, impliseer om hard, onredelik en oorrompelend op iemand toe te slaan. Hierdie woord word ook in 1 Timoteus 5:1 gebruik, waar Timoteus verbied word om 'n ouer man skerp te vermaan. Die bedienaar se optrede moet eerder sodanig wees dat hy 'n geveg of rusie sal vermy (amachos -1 Tim. 3:3). In Titus 1:7 word die verdere vereiste gestel dat die bedienaar nie opvlieënd (me orgilos) moet wees nie. Hy moet met ander woorde nie met 'n (woord)geveg begin nie. Hierdie vereiste hou verband met die vereiste wat in 2 Timoteus 2:24 aan die bedienaar gestel word, naamlik dat hy "kwaad [letterlik slegte dinge] moet kan dra".

\subsubsection{Bedienaar en geborgenheid}

Die vereistes van selfbeheersing bring die aspek van die geborgenheid van die bedienaar self in die visier. Op menslike vlak is dit bykans onmoontlik om altyd kwaad te kan dra of om 'n rusie te kan 
vermy. Daarvoor word die dieper dimensie van geborgenheid vereis. Hierdie saak kom in die besonder na vore in die roeping tot bedienaar.

In die pastorale briewe kom die roeping van die bedienaar vyf keer ter sprake, naamlik in 1 Timoteus 1:18 en 2:5-7, in 2 Timoteus 1:911 en 2:1-2 asook in Titus 1:4-5 (vgl. Venter, 2004:432; 2009:141142). ' $n$ Nadere verkenning van hierdie gedeeltes bring aan die lig dat roeping weergegee word met uitdrukkings soos "opdrag gee", "aanstel" en "toevertrou". Die Griekse uitdrukking tithemi wat hier gebruik word om roeping aan te dui, het as konnotasie die afsondering vir 'n taak deur iemand hoër as jyself - dus iemand met gesag - asook om daardie taak te verrig en persoonlik daarby betrokke te wees (vgl. Quinn \& Wacker, 2000:141). 'n Verdere aspek wat uit die verkenning van hierdie vyf gedeeltes na vore kom, is dat die roeping tot bedienaar gefundeer moet word in die ingrypende versoeningswerk van Christus. In sy dienswerk en in die vereiste om selfbeheersing te beoefen, vind die bedienaar sy diepste geborgenheid in God en in die roeping wat tot hom van God kom.

Die stelling dat die bedienaar sy geborgenheid in God vind, hang ook saam met die aspek dat God self, die Heilige Gees, aan die bedienaar die vermoë tot selfbeheersing gee. Dit is opvallend dat in Galasiërs 5:23 verskillende aspekte van die vrug van die Gees genoem word, en dat die eerste of grondliggende vrug die liefde is. Die hoogste vrug van die Gees wat as 't ware klimakties heel laaste genoem word, is selfbeheersing (engkrates).

Selfbeheersing kan net beoefen word in diepe gemeenskap met die Heilige Gees en die hoogste aspek van die vrug van die Heilige Gees is selfbeheersing.

\section{Perspektiewe op sosiale intelligensie}

\subsection{Metateoretiese perspektiewe}

Wesenlik impliseer emosionele intelligensie (EI) dat dit die bedienaar tot selfinsig in sy eie gevoelens, motiewe en emosies bring. Sosiale intelligensie (SI) bring die bedienaar tot insig in ander persone se emosies, sosiale situasies en vaardighede om 'n bepaalde situasie te kan hanteer (Venter, 2009:144-145; Goleman, 2006; Albrecht, 2008:1).

'n Besondere bydrae van Goleman (2006:330) is dat hy op grond van die byeenbring van navorsingsresultate uit die Neurologie ver- 
bande lê tussen 'n bepaalde tipe sosiale optrede en sekere breinfunksies. Afgesien van vele ander funksies het die brein ook 'n bepaalde instelling en "ratwerk" vir die sosiale verbondenheid en funksies van 'n mens.

\subsubsection{Dimensies van sosiale intelligensie}

Goleman (2006:331) sien selfbewussyn en selfbestuur as die vernaamste komponente van emosionele intelligensie. Onder die belangrikste dimensies van sosiale intelligensie sonder hy veral 'n aspek soos sosiale bewustheid uit. Sosiale bewustheid omvat die vermoë om 'n ander se innerlike situasie gou aan te voel, en sy/haar gevoelens en gedagtes te verstaan. Hierin speel die volgende vaardighede 'n deurslaggewende rol: empatie (die vaardigheid om te voel wat 'n ander voel deur nie-verbale seine op te vang, maar ook 'n akkurate begrip vir ' $n$ ander se gevoelens, gedagtes en intensies) en die vermoë om jouself op 'n ander "in te stel" deur ontvanklik te luister. Goleman (2006:331) voeg social cognition as 'n verdere vereiste by en bedoel daarmee dat 'n pastor moet weet hoe die sosiale wêreld "werk".

Om egter net oor hierdie vaardighede te beskik, waarborg nog nie effektiewe sosiale interaksie nie. Om op sosiale vlak effektief te kommunikeer vereis ook die volgende: sinkronisering, met ander woorde om ook op nie-verbale vlak interaksie te hê; om jouself op 'n effektiewe wyse aan te bied, byvoorbeeld in die formulering van en in die gesag waarmee oor 'n saak gekommunikeer word; om die uitkoms van sosiale interaksie te verfyn; en laastens om vir 'n ander se behoeftes om te gee en in ooreenstemming daarmee op te tree (Goleman, 2006:84).

Albrecht (2008:2-3; vgl. ook 2005:2) wys op die navorsing van Gardner in die kennisveld van sosiale intelligensie. Gardner onderskei tussen interpersoonlike intelligensie (sosiale intelligensie) en intrapersoonlike intelligensie (emosionele intelligensie).

Albrecht bevind dat sosiale intelligensie as 't ware deur verskillende lense na sosiale interaksie kyk. Hierdie aktiwiteit vind plaas deur jouself te evalueer ten opsigte van jou eie effektiwiteit in die hantering van ander, en deur jou eie interaksiestyl in verskillende situasies te beoordeel (Albrecht, 2008:3; Venter 2009:147). 


\subsubsection{Sosiale vaardighede}

Wat sosiale vaardighede betref, onderskei Albrecht (2008:3-4) die volgende vyf basiese vaardighede:

- 'n Bewustheid en 'n vermoë om die sosiale konteks waarbinne sosiale interaksie plaasvind en mense se gedrag, optrede en reaksie beïnvloed, te verstaan.

- 'n Vaardigheid om houding (presence) te interpreteer. Houding dui onder andere op die indruk wat iemand skep, die boodskap wat van iemand se optrede uitgaan, gedrag en vaardigheid en sy/haar gevoel van eiewaarde soos dit deur ander beleef word.

- Die eienskap van egtheid wat eerlikheid en opregtheid inhou, sodat ander kan aanvoel dat jou optrede in ooreenstemming met jou waardes is.

- Helderheid (clarity) het veral betrekking op die vermoë om gedagtes duidelik te formuleer. Hierdie vaardigheid hang saam met bepaalde kommunikasievermoëns soos die aksie van kreatiewe luister, terugvoer, samevatting, kernagtige en metaforiese formulering.

- In sosiale intelligensie behels empatie nie net om 'n bepaalde gevoel uit te straal of te formuleer nie, maar veral ook om 'n wederkerige gevoel te skep tussen 'n kommunikeerder en sy gespreksgenoot.

Die uitwerking van die toepassing van kommunikasievaardighede (of die gebrek daaraan) verdeel Albrecht (2008:1) in twee teenoorgestelde effekte, naamlik 'n negatiewe of 'n "vergiftigende" (toxic) effek en 'n opbouende of "voedende" (nourishing) effek. 'n Negatiewe uitwerking in kommunikasie vind met ander woorde neerslag in gevoelens en gedrag van vernedering, aggressie, frustrasie, skuld en ontoereikendheid. 'n Opbouende effek kom na vore in gevoelens van eiewaarde, respek, goedkeuring, bemoediging en opgewassenheid vir ' $n$ taak. Herhalende negatiewe kommunikasie en optrede in kommunikasie met ander dui op laevlak-sosiale intelligensie en die teenoorgestelde op hoëvlak-sosiale intelligensie.

Saamgevat: Sosiale intelligensie word aangewend en toegepas in kommunikasie wat na buite gerig word. Dit omvat aspekte soos die bewustheid van 'n sosiale konteks waarin kommunikasie plaasvind, houding (presence), egtheid, helderheid en empatie gepaard met vaardighede wat op nie-verbale vlak na vore kom en om besorgd te 
wees en die uitwerking van interaksie met ander in berekening te bring.

\subsection{Basisteoretiese perspektiewe op die veld van sosiale intelligensie (SI)}

'n Kardinale punt wat uit die metateoreties besinning oor sosiale intelligensie na vore gekom het, is die aspek van verhoudingsvorming deur die bedienaar.

Op basisteoretiese vlak kan, wat verhoudingsvorming betref, veral na die volgende twee kernsake verwys word:

\subsubsection{Bedienaar en verhoudingsvorming}

In hierdie verband kan gelet word op Paulus se gebruik van die metafoor van die huisgesin in 1 Timoteus 3:4. Hier word 'n korrelasie gestel tussen die bedienaar se optrede in sy eie gesin en in die gemeente, "die huisgesin van die lewende God" (1 Tim. 3:15). Die metafoor van die huisgesin druk onderlinge verhouding uit (Venter, 2009:139; Stott, 1997:120). Die klimaat waarbinne die bedienaar optree, is dus dié van onderlinge geloofsverhouding. Hierdie onderlinge verhouding vind plaas deur identifikasie tussen die bedienaar en die lidmaat. Hiervan is sprake in Paulus se optrede teenoor die bedienaar Timoteus. Hy spreek Timoteus aan as "my ware kind" en as "my seun" (1 Tim. 1:2 en 2:1). Hierdie aanspreekvorm druk nie net verhouding uit nie, maar ook bedieningsidentifikasie.

\subsubsection{Bedienaar en empatie}

Wat bedienaar en empatie betref, word kortliks aandag gegee aan Romeine 12. In vers 1 word 'n uiteensetting gebied van God se groot ontferming. In verse 9-21 volg riglyne vir die praktyk van die nuwe lewe van gelowiges in verhouding met mekaar. Die effek van die nuwe lewe kan vergelyk word met drie wyerwordende sirkels (Venter, 2005a:217-237). Binne die nouste sirkel, die gemeente, moet die liefde opreg wees (v. 9). Binne die tweede sirkel (v. 17) staan die bevel: "Wees goedgesind teenoor alle mense". In vers 10 word verder gestel: "Betoon hartlike broederliefde" en in vers 18: "Leef in vrede met alle mense". Laastens word in vers 13 beveel: "Help die medegelowiges in hulle nood" en verder: "As jou vyand honger of dors is, gee hom kos en water". Dit gaan hier dus om omvattende liefdesbetoon in opregtheid. Maar dit gaan ook om empatie. Vers 13 veronderstel 'n benadering in empatie: "Help die mede- 
gelowiges in hulle nood" en in vers 15: "Wees bly saam met die wat bly is en treur saam met die wat treur".

Dit is egter nie net in die Romeinebrief waarin aanduidings van empatie na vore kom nie. Paulus se bediening in empatie aan die gemeente van die Tessalonisense word duidelik uit sy gebruik van die driedubbele metafoor van vader, moeder en kinders. In 1 Tessalonisense 2:7 stel Paulus: "Ons was liefdevol en sag teenoor julle soos 'n ma wat haar kinders vertroetel" en in 1 Tessalonisense 2:11 en 12 gaan hy voort en stel: “... soos 'n pa sy kinders, het ons elkeen bemoedig en aangespoor en dit op die hart gedruk om tot eer van God te lewe". Die gebruik van die metafore vader, moeder en kinders verwys na 'n empatiese ingesteldheid, gesindheid en optrede van 'n bedienaar waar gevoelens uitgespreek en gewys word (Venter, 2009:144). Binne hierdie empatiese verhouding kan bediening individualiserend gerig word, en met inagneming van die persoon se konteks en die saak wat na vore gebring word, kan die Skrif persoons- en situasiegerig gehanteer word. As die bedieningswyse individualiserend gerig word, en die houding dié van empatie is, is dit ook moontlik om op 'n meer toepaslike wyse voorbidding te doen en in die gebed 'n gespreksgenoot se gevoelens te verwoord.

\section{Praktykteoretiese perspektiewe}

\subsection{Gawes en die ontginning van gawes}

Veral uit die basisteoretiese besinning oor aspekte wat verband hou met verstandelike, emosionele en sosiale intelligensie, het na vore gekom dat die gawes deur Christus en die Heilige Gees gegee word met die oog op die toerusting en opbou van die gemeente op die konkrete vlak van hulle eie bestaan en dienswerk.

Die vereistes wat aan die bedienaar gestel word en die gawes wat hy/sy ontvang, moet egter vasgestel word, sigbaar word en aangewakker word.

Hierdie gawes en vaardighede is kontroleerbaar en kan prakties geslyp, verdiep en afgerond word deur aspekte van die kennisveld van verstandelike, emosionele en sosiale intelligensie prakties toe te pas. Die volgende word aan die hand gedoen.

\subsection{Toerusting deur die bedienaar self}

Die bedienaar se helder selfbewussyn van wie hy is, wat sy gawes en swakhede is, waarin hy sy geborgenheid vind, waar sy vrese lê, 
hoe hy stres hanteer en watter negatiewe (vergiftigende) uitwerking 'n gebrek aan selfbeheersing kan inhou, kom hier in die visier.

'n Vermaningsituasie of spanningsreaksie wat byvoorbeeld in 'n vergadering geaktiveer word op grond van die lower road (die veg- of vlugreaksie) in die werking van die amigdala, kan positief gekanaliseer word deur nie onmiddellik op affrontering, misverstand of belediging te reageer nie. Selfbeheersing vereis prakties dat eerstens vasgestel word of 'n ander persoon reg verstaan of aangehoor is, en of die feite korrek is. Selfbeheersing vra ook soms dat die bedienaar self moet stilbly of in 'n uiterste geval, homself tydelik kalm aan die situasie onttrek.

Die bedienaar se hantering van aggressie hang ook direk saam met die beoefening van sy eie spiritualiteit. Sy eie omgang met God deur Skrifstudie, bepeinsing en deur voortdurende gebed om selfbeheersing, bring ook verdieping en 'n nuwe perspektief op die saak waarvoor gebid word.

\subsection{Toerusting van bedienaars deur opleidingsinstansies}

Op die vlak van verstandelike, emosionele en sosiale intelligensie kan aandag gewy word aan die toerusting van bedienaars deur geleenthede vir voortgesette teologiese opleiding of gereelde seminare te skep. Tydens sulke geleenthede kan deur middel van werksessies aspekte van verstandelike, emosionele en sosiale intelligensie aan die orde gestel en prakties getoets word. Hierdie tipe aanbiedings moet egter nie op blote rasionele vlak beweeg nie. 'n Goedbeplande leerplan en twee seminare per jaar saam met praktyktoespitsing kan 'n (nuwe) bewustheid van en 'n verdieping in die toepassing van aspekte vanuit die veld van verstandelike, emosionele en sosiale intelligensie fasiliteer. Sulke aanbiedings moet 'n geleentheid vir die bedienaar bied om ook te besin en te evalueer op watter wyse hy na ander "oorkom", met ander woorde hoe die aspek van "ministering for" ook omskep kan word in "being for" die gemeente. Aspekte soos die vorming en onderhouding van die pastorale verhouding, die plek en funksionering van empatie in pastorale werk, die hantering van aggressie en stres, verhoudingsvorming, die kreatiewe luisteraksie, individualiserende gesprekvoering, helder kommunikasie, egtheid, opregtheid, kongruensie tussen 'n persoon en die optrede van die bedienaar, die houding (presence) wat hy/sy uitstraal en hoe dit deur ander beleef word, is kernsake wat aandag in sodanige voortgesette toerusting kan ontvang. 
In die opleiding van voornemende bedienaars ontvang sommige van hierdie sake reeds in mindere of meerdere mate aandag. Verstandelike intelligensie word in die psigometriese toetsing, begeleiding en voortgaande gesprekke by toelating betrek, maar ook tydens die voortsetting van die studie van aanstaande predikante.

Gegewens uit psigometriese toetsing op die vlakke van emosionele en sosiale intelligensie bied meerdere geleenthede en moontlikhede om die selfbewussyn, vaardighede, hantering van aggressie, asook empatie en verhoudingsvorming te verdiep.

Die bedienaar wat homself voortdurend vanuit die praktyk en deur middel van sy omgang met die Woord van God toerus, word ook toegerus deur die Heilige Gees. Dit is egter noodsaaklik dat die bedienaar ook bewusgemaak word van moontlike gebreke in die manier waarop hy sy herderlike werk verrig. 'n Bedienaar wat net verstandelik intelligent is, is nie altyd noodwendig emosioneel of sosiaal intelligent nie. 'n Bedienaar kan 'n moeilike gemeentesituasie byvoorbeeld met sy verstand analiseer en ontleed, maar hy het nie die nodige empatie om 'n plofbare situasie te ontlont nie. Dit kan ook gebeur dat hy wel empatie het en homself in iemand anders se probleem kan inleef, maar nie die vermoë het om werkbare oplossings uit te wys nie.

Die ideaal sou daarom wees om sekere modules in die aanbied van die vak Pastoraal, en spesiale opleidingseminare vir predikante, aan tersaaklike aspekte van verstandelike, emosionele en sosiale intelligensie te wy - juis sodat goedtoegeruste bedienaars van die Opperherder sy kudde kan bystaan en vertroos.

\section{Geraadpleegde bronne}

ALBRECHT, K. 2005. Social intelligence: the new science of success. New York: Wiley.

ALBRECHT, K. 2008. Social intelligence: the new science of success: KAI home page. http://www.karlalbrecht.com/booksocialintelligence.htm Date of access: 15 Feb. 2008.

ARMSTRONG, R.S. 1990. The pastor-evangelist in the parish. Westminster: John Knox.

ARNDT, W.F. \& GINGRICH, F.W. 1979. A Greek-English Lexicon of the New Testament and Other Early Christian Literature. Chicago: Chicago University Press.

BECHARA, A., TRANEL, D. \& DAMASIO, A.R. 2000. Poor judgment in spite of high intellect: neurological evidence for emotional intelligence. (In Bar-on, R. \& Parker, J.D.A., eds. The handbook of emotional intelligence. San Francisco: Jossey-Bass. p. 192-214.) 
BEDELL, J.R. \& LENNOX, S.S. 1997. Handbook for communication and problem-solving skills. New York: Wiley.

BURNARD, P.B. 1992. Knowing yourself: self-awareness activities for nurses. London: Scutari.

DREYER, J.S. 2008. Practical theology and human well-being: an exploration of a multidimensional model of human action as conceptual framework. Praktiese teologie in Suid-Afrika, 23(3):3-22.

DREYER, Y. 2003. Beyond psychology: spirituality in Henri Nouwen's pastoral care. Hervormde teologiese studies, 59(3):715-733.

FOURIE, J.H.V.S. 2008. "Medelye-moegheid": 'n pastorale benadering. Potchefstroom: Noordwes-Universiteit. (Ph.D.-proefskrif.)

GARDNER, H. 1993. Multiple intelligencies: the theory in practice. New York: Basic Books.

GOLEMAN, D. 1997. Emotional intelligence. New York: Bantam.

GOLEMAN, D. 1998. Working with emotional intelligence. London: Bloomsbury.

GOLEMAN, D. 2006. Social intelligence: the new science of human relationships. London: Hutchinson.

GOLEMAN, D., BOYATZIS, R. \& McKEE, A. 2002. Primal leadership: realizing the power of emotional intelligence. Boston: Harvard Business School Press.

GREENFIELD, G. 2001. The wounded minister. Grand Rapids: Baker.

GROBBELAAR, K.G. 2007. Hulpverlening tot streshantering by predikante van die Gereformeerde Kerke in Suid-Afrika (GKSA): 'n pastorale studie. Potchefstroom: Noordwes-Universiteit. (Ph.D.-proefskrif.)

HUGO, C.J. 2008. From trauma support to pastoral care for survivors of trauma: a model for pastoral care. Praktiese teologie in Suid-Afrika, 23(3):107-126.

KIM, H.K. \& VENTER, C.J.H. 1998. Preacher and spirituality: perspectives from the pastoral epistles. In die Skriflig, 32(2):161-179.

KRUGER, F.P. \& VENTER, C.J.H. 2000. Prediker, preekgesindheid en die toerusting van die gemeente. In die Skriflig, 34(2):173-194.

KRUGER, S.F. 2000. Menslike persoonlikheid en toerustende herderlike bediening: aspekte van 'n metateorie, basisteorie en praktykteorie. Potchefstroom: PU vir CHO. (Th.D.-proefskrif.)

KRUGER, S.F. \& VENTER, C.J.H. 2001. Die verhouding tussen psigologie en praktiese teologie: aspekte van die onderlinge waarde van die verhouding. In die Skriflig, 35(4):557-574.

LeDOUX, J. 1996. The emotional brain: the mysterious underpinnings of emotional life. New York: Simon \& Schuster.

LOUW, J.P. \& NIDA, E.A. 1989. Greek-English Lexicon of the New Testament Based On Semantic Domains. Vols. 1 \& 2. Cape Town: Bible Society of South Africa.

MONTOYA, A. 2000. Preaching with passion. Grand Rapids: Kregel.

NEL, M. 2001. Ek is die verskil: die invloed van persoonlikheid in die prediking. Bloemfontein: Christelike Lektuurfonds (CLF).

NEL, M. 2005. Public pastoral leaders: the purpose of theological training. In die Skriflig, 39(3):41-462.

NOTLE, P.S. \& DREYER, Y. 2009. Pastors as gewonde genesers: outobiografiese pastoraat as heelmiddel vir emosionele verwonding en verlamming by pastors. Hervormde teologiese studies, 65(1), Art \# 158, 9 pages. D01:10.4102/hts.v65i1.158 Datum van gebruik: 27 Okt. 2009. 
QUINN, J.D. \& WACKER, W.C. 2000. The first and second letters to Timothy. Grand Rapids: Eerdmans.

SALOVEY, P., MAYER, J.D. \& CARUSO, D. 2002. The positive psychology of emotional intelligence. (In Snyder, C.R. \& Lopez, S.J., eds. Handbook of positive psychology. Oxford: Oxford University Press. p. 159-171.)

STOTT, J.R.W. 1997. The message of Timothy and Titus. Leicester: InterVarsity.

TAYLOR, G.J. \& BAGBY, R.M. 2000. An overview of the alexithymia construct. (In Bar-on, R. \& Parker, J.D. The handbook of emotional intelligence. San Francisco: Jossey-Bass. p. 40-67.)

VAN DER WALT, T. 2007. Die Messias het gekom! 'n Gids in die Evangelies vir toegewyde Bybel-studente. Potchefstroom: Potchefstroomse Teologiese Publikasies.

VAN JAARSVELD, P. 2003. Die hart van 'n wenner: ontwikkel jou emosionele intelligensie. Wellington: Lux Verbi.BM.

VENTER, C.J.H. 1976. Die bediening van die versoening aan die bejaarde: 'n pastorale studie in die lig van die pastorale briewe. Potchefstroom: Pro Rege.

VENTER, C.J.H. 1999. Die spiritualiteit van die bedienaar met verwysing na sy toerustingstaak. In die Skriflig, 33(2):187-202.

VENTER, C.J.H. 2004. Die predikant wat houe uitdeel. In die Skriflig, 38(3):429449.

VENTER, C.J.H. 2005a. Prediking wat transformeer - prakties-teologiese gesigspunte. In die Skriflig, 39(2):217-237.

VENTER, C.J.H. 2005b. Aspekte van emosionele intelligensie in die lewe van die nuwe mens. In die Skriflig, 39(1):1-25.

VENTER, C.J.H. 2009. Pastor and social intelligence. (In Pieterse, H.J.C. \& Thesnaar, C.H., eds. A faithful witness. Wellington: Bybelmedia. p.137151.)

VERMEULEN, S. 1999. EQ emotional intelligence for everyone. Rivonia: Zebra.

\section{Kernbegrippe:}

emosies: ontleding van

intelligensie: verstandelik, emosioneel, sosiaal

pastorale briewe

selfinsig

toerusting: bedienaar se

\section{Key concepts:}

emotions: analysis of

equipment: pastors'

intelligence: cognitive, emotional, social

pastoral epistles

self-awareness 
